\title{
Kolaborasi Musik Rock dengan Alat Musik Tradisional Polopalo
}

\author{
Febriyando \\ IAIN Manado \\ Pos-el: febriyando@iain-manado.ac.id \\ DOI: $10.32884 / i d e a s . v \%$ vi \%i.293
}

\begin{abstract}
Abstrak
Polopalo adalah alat musik khas Gorontalo, yang sudah mulai ditinggalkan oleh generasi masa kini. Akan sangat menarik jika alat music ini dikolaborasikan dengan alat musik modern. Oleh karena itu, penelitian ini bertujuan untuk mengetahui cara yang efektif dalam mengolaborasikan musik rock dengan alat musik polopalo. Pendekatan yang digunakan dalam penelitian ini adalah pendekatan kualitatif. Hasil penelitian menunjukkan bahwa keterbatasan nada yang dihasilkan dari bunyi alat musik polopalo menjadi suatu hambatan dalam proses kolaborasi, sehingga cara yang paling efektif dalam kolaborasi yang penulis lakukan adalah dengan menjadikan alat musik polopalo tersebut sebagai alat musik perkusi.
\end{abstract}

\section{Kata kunci}

Polopalo, pendidikan

\section{Abstract}

The polopalo is a typical Gorontalo musical instrument, which the current generation has begun to abandon. It would be very interesting if this musical instrument was collaborated with modern musical instruments. Therefore, this study aims to determine the effective way to collaborate rock music with the Polopalo musical instrument. The approach used in this study is a qualitative approach. The results showed that the limitation of the tone produced from the sound of the polopalo musical instrument became an obstacle in the collaboration process, so that the most effective way of collaboration that the author did was to make the polopalo instrument as a percussion instrument.

\section{Keywords}

Polopalo, education

\section{Pendahuluan}

Salah satu alat musik tradisional Indonesia yang berasal dari Provinsi Gorontalo adalah alat musik polopalo. Polopalo merupakan alat musik yang terbuat dari bambu, yang pada zamannya saat itu dimainkan rakyat Gorontalo hanya pada waktu-waktu tertentu. Hal itu dilakukan pada saat masyarakat telah selesai melaksanakan panen raya atau pada waktu bulan terang (bulan purnama).

Sekitar abad ke-18, polopalo bukanlah merupakan alat musik, namun lebih banyak digunakan sebagai alat komunikasi yang dimainkan untuk memanggil 


\section{Volume: 6 \\ Nomor : 3 \\ Bulan : Agustus \\ Tahun : 2020

masyarakat dalam acara adat di Gorontalo. Pada zaman dahulu dikenal dengan nama Tonggobi, kemudian di tahun 1980-an seniman Rusdin Palada memiliki inisiatif untuk mengalihkan polopalo ini menjadi alat musik. Mulanya, Rusdin Palada mencermati pembentukan nada pada alat musik tersebut, baik dengan mengubah bentuk moncongnya menjadi lebih tipis, atau memperbesar lubang dan gagangnya.

Pada perkembangannya, polopalo menjadi sebuah alat yang memiliki fungsi penting di dalam kegiatan adat istiadat Gorontalo, hingga kemudian para pengrajin alat musik polopalo melakukan berbagai cara untuk memenuhi kebutuhan masyarakat yang di dalam pola pikirnya telah dipengaruhi oleh berbagai perkembangan global dengan tuntutan kemajuan secara instan dari berbagai faktor (Suwardi Bay dan Farha Daulima, Alat Musik Tradisional Daerah Gorontalo, Forum Suara Perempuan, Gorontalo 2006, p. 61).

Polopalo memiliki keunikan tersendiri seperti pemilihan bahan baku, cara memainkan dan waktu memainkannya. Bahan baku utamanya adalah bambu. Bambu sendiri memiliki dua jenis bambu yaitu bambu air dan bambu pagar, namun untuk alat musik polopalo menggunakan bambu air, karena bambu air tersebut dapat menghasilkan bunyi yang lebih nyaring dan sedikit halus.

Keunikan lainnya yaitu polopalo hanya dimainkan pada malam kamis dan malam minggu saja, karena masyarakat Gorontalo percaya bahwa malam-malam tersebut adalah malam yang istimewa. Permainannya pun hanya pada malam hari, karena dalam memainkannya memerlukan ketenangan jiwa yang menurut masyarakat Gorontalo pada malam tersebut yang paling spesial bila dibandingkan dengan malam lain.

Di zaman sekarang, pengolaborasian antara musik tradisional dan musik popular bukan merupakan hal baru lagi. Banyak alat musik tradisional seperti gamelan, angklung, sampek dan masih banyak lagi alat musik yang sudah pernah dikolaborasikan dengan musik populer. Salah satunya di Yogyakarta yang paling mencolok terjadi di daerah Malioboro. Para pengamen di Malioboro hampir sebagian besar melakukan kolaborasi dengan menggunakan alat musik tradisional seperti angklung, gamelan dengan alat musik populer seperti snare, drum, simbal, kontra 
bass, dan lain sebagainya. Kolaborasi tersebut sangat bagus untuk dijadikan inspirasi bagi musisi yang mempunyai ekplorasi musik sejenis.

Eksistensi polopalo belakangan ini semakin tergusur dengan pesatnya media digital yang merambah menurunnya penerapan alat musik tradisi polopalo sehingga tergantikan oleh alat-alat elektronik musik padahal secara organologi polopalo sendiri masih mampu untuk dielaborasi dengan alat-alat musik elektronik. Oleh karena itu, penulis memiliki gagasan untuk mengkolaborasikan alat musik polopalo daerah Gorontalo dengan alat musik barat. Hal tersebut belum pernah dilakukan dikarenakan semakin lama alat musik polopalo tersebut semakin tidak digemari di kalangan anak muda bahkan kalangan orang dewasa, sedangkan di Gorontalo, musik barat banyak digemari di kalangan anak muda sampai orang dewasa.

Alat musik polopalo ini sangat berbeda dengan alat musik lainnya, karena bunyi yang dihasilkan dari setiap polopalo yang satu dengan yang lainnya sangatlah berbeda. Hal tersebut dikarenakan setiap bahan bambu yang dipotong saat proses pembuatan sangat berbeda dan dibuat dengan takaran pemotangan yang tidak sama. Inilah yang menjadi salah satu kendala penulis dalam menciptakan karya dan aransemen saat pengkolaborasian musik modern dan alat musik polopalo.

\section{Metode}

Pendekatan yang digunakan dalam penelitian ini adalah pendekatan kualitatif, yaitu cara kerja penelitian yang menekankan pada aspek pendalaman data demi mendapatkan kualitas dari hasil suatu penelitian, dengan mekanisme kerja penelitian yang mengandalkan uraian deskriptif kata atau kalimat yang disusun secara sistematis dan cermat mulai dari menghimpun data, menafsirkan, hingga melaporkan hasil penelitian (Ibrahim, 2015, p. 52), dapat diartikan pula sebagai pendekatan penelitian yang berlandaskan pada filsafat postpositivisme, digunakan untuk meneliti pada kondisi objek yang alamiah, dimana peneliti sebagai instrumen kunci. Teknik pengumpulan data dilakukan secara triangulasi (gabungan), analisis bersifat induktif/ kualitatif, dan hasil penelitiannya lebih menekankan makna daripada generalisasi (Sugiyono, 2016, p. 14).

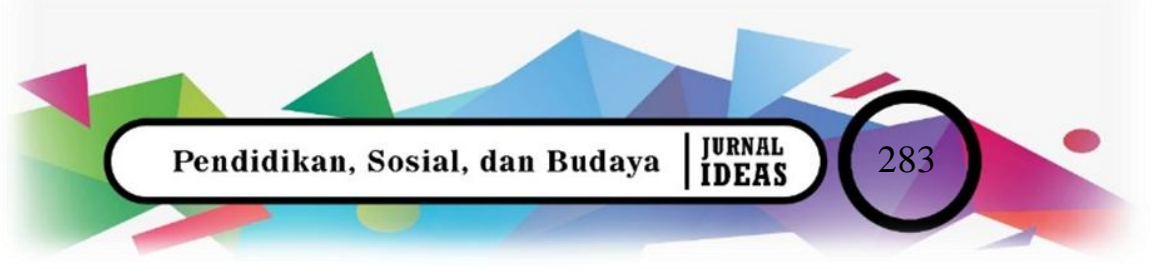




\section{Volume: 6 \\ Nomor : 3 \\ Bulan : Agustus \\ Tahun : 2020

Metode yang digunakan adalah metode deskriptif, yaitu salah satu cara kerja penelitian yang bersifat melukiskan, menggambarkan, meringkaskan berbagai kondisi, situasi atau berbagai variabel yang diteliti, dan memaparkan keadaan objek yang diteliti sebagaimana apa adanya, sesuai dengan situasi dan kondisi ketika penelitian tersebut dilakukan (Ibrahim, 2015, p. 59). Variabel yang menjadi fokus penelitian ini adalah seni dan budaya serta perspektif eksistensi alat musik tradisional Gorontalo (polopalo)

Ada tiga jenis teknik pengumpulan data yang penulis lakukan dalam menjabarkan eksistensi polopalo sebagai kekayaan budaya daerah Gorontalo. Di antaranya sebagai berikut.

1. Observasi

Observasi yang dimaksud adalah pengamatan terhadap kondisi pelestarian alat musik tradisional Gorontalo yang dikorelasikan dengan alat musik Barat. Beberapa hal yang dimaksud meliputi kegiatan kesenian, pemberitaan, publikasi, dan dokumentasi kegiatan eksistensi polopalo dalam seni pertunjukan.

2. Wawancara

Wawancara disini dilakukan dengan tahapan teknik wawancara pendalaman terhadap isu perkembangan musik tradisional polopalo di Gorontalo. Narasumber dikatagorikan dalam beberapa aspek yaitu antropolog, budayawan dan masyarakat pegiat alat musik tradisional polopalo.

3. Analisis dokumen

Adapun opsi selain observasi dan wawancara, pengumpulan data juga dilakukan dengan memanfaatkan dokumen pembanding baik sifatnya tertulis, rekaman audio, rekaman video dan foto. Data yang bersumber dari dokumen tersebut nantinya akan memperkaya informasi penelitian yang kemudian akan di identifikasi dalam bentuk makna korelasi penelitian terkait. 


\section{Hasil dan Pembahasan}

Penjabaran hasil penelitian dilakukan dari pandangan historis hingga fenomena terkini terkait perkembangan alat musik tradisional polopalo.

\section{Sejarah Polopalo}

Gorontalo merupakan salah satu provinsi yang memisahkan diri dari Provinsi Sulawesi Utara pada tahun 2001, memiliki jenis kebudayan dan adat istiadat yang beraneka ragam. Salah satu kesenian sebagai bagian dari kebudayaan daerah Gorontalo yang cukup terkenal yaitu alat musik tradisional polopalo.

Menurut masyarakat Gorontalo, alat musik tradisional polopalo merupakan alat musik asli rakyat Gorontalo, namun pada perkembangannya, ternyata ditemui ada alat musik daerah lain yang hampir serupa dengan alat musik ini yakni alat musik Sasaheng yang berkembang didaerah Sangihe Talaud dan Bonsingdari daerah Bolaang Mongondow, Manado, Sulawesi Utara.

Pada tahun 60-an sampai tahun 90-an, polopalo biasanya dimainkan pada waktu-waktu tertentu, yang pada hari tersebut merupakan hari yang spesial menurut masyarakat Gorontalo. Contohnya, pada waktu masyarakat daerah Gorontalo telah selesai melaksanakan panen raya, pergantian musim atau pada waktu bulan terang (bulan purnama).

Tradisi memainkan alat musik polopalo dilaksanakan tanpa menunggu perintah atau komando, dalam hal ini masyarakat tergerak dengan sendirinya karena merasa harus merayakan atau bergembira bersama dalam mensyukuri hari yang indah atau hari yang spesial tersebut. Biasanya musik tradisonal polopalo itu dimainkan kirakira pukul 22.00 sampai pukul 01.00 waktu setempat untuk memanggil masyarakat berkumpul bersama.

Berbeda dengan alat musik tradisional lainnya, polopalo memiliki keunikan tersendiri seperti pemilihan bahan baku, cara memainkan dan waktu memainkannya. Bahan baku utamanya adalah bambu. Bambu sendiri memiliki dua jenis bambu yaitu bambu air dan bambu pagar namun untuk alat musik polopalo sendiri, khususnya menggunakan bambu air.

Keunikan lainnya yaitu polopalo hanya dimainkan pada malam kamis dan malam minggu saja, karena masyarakat Gorontalo percaya bahwa malam-malam 


\section{Volume: 6 \\ Nomor : 3 \\ Bulan : Agustus \\ Tahun : 2020

tersebut adalah malam yang istimewa bila dibandingkan dengan malam lain, kemudian permainannya pun hanya pada malam hari, karena dalam memainkannya memerlukan ketenangan dan suasana yang tenang.

Alat musik polopalo pada jamannya sering dilombakan. Biasanya dalam sebuah lomba, juri hadir bersamaan di satu tempat, namun dalam lomba polopalo, jurinya berada jauh dengan jarak $+1 \mathrm{~km}$ atau 1000 meter. Hal ini dilakukan untuk bisa mendengar suara / bunyi yang paling nyaring. Penentuan juarapun didapatkan dari suara ketukan yang terdengar paling nyaring.

Seiring dengan berkembangnya jaman, popularitas alat musik polopalo saat ini sepertinya tidak lagi diminati masyarakat Gorontalo. Hal ini disebabkan kurangnya upaya pelestarian yang dilakukan untuk tetap mempertahankan keberadaan alat musik tersebut, dan akan sangat disayangkan apabila alat musik ini hilang di masa yang akan datang. Saat ini, masyarakat lebih tertarik menggunakan alat musik modern dari pada tradisional. Bila dicermati dengan baik, alat musik polopalo sangat unik baik dari cara pemilihan bahannya, cara memainkannnya, serta nada-nada yang ditimbulkan melalui pukulan, namun keunikan ini hanya menjadi sebatas cerita sejarah saja tanpa ada pelestarian dalam bentuk fisik maupun non fisik untuk tetap mempertahankan keberadaannya.

\section{Esensi dan organologi Alat Musik Polopalo}

Alat musik tradisional polopalo merupakan alat musik jenis idiofon yaitu ragam alat musik yang badan alat musik itu sendiri merupakan sumber bunyi, baik dipalu, diguncang atau dibunyikan dengan saling dibenturkan. Dalam artian bahwa ketika polopalo tersebut di pukul atau sebaliknya memperoleh pukulan, bunyinya akan dihasilkan dari proses bergetarnya seluruh tubuh polopalo tersebut.

Alat musik polopalo adalah alat musik yang bahan dasarnya terbuat dari bambu, bentuknya menyerupai garputala raksasa. Polopalo mendapatkan penyempurnaan pada beberapa hal, salah satunya adalah dengan adanya polopalo dibuatkan sebuah pemukul dari kayu yang dilapisi karet agar mempermudah dan membantu dalam proses memainkan alat musik polopalo.

Awal sebelum dinamakan polopalo, nama aslinya adalah tonggobi, yang kemudian pada tahun 1980-an ada inisaitif dari seniman Rusdin Palada, mengalihkan 
tonggobi menjadi polopalo sebagai alat musik tradisional Gorontalo. Istilah polopalo berarti terbelah dengan kata aslinya popa-popalo.

Arthur Galuanta salah satu tokoh musik di Gorontalo mengasumsikan bahwa, sebenarnya alat musik polopalo dapat di kembangkan dari 2 nada atau lebih, dalam artian dapat dikembangkan jenis organologinya sehingga akan menghasilkan beberapa buah alat musik polopalo dalam bentuk dan nada yang berbeda.

Polopalo yang telah menjadi beberapa buah nada tersebut, akan dimainkan oleh beberapa orang dengan menyesuaikan komposisi yang telah dibuat. Secara otomatis musik polopalo dengan variasi nada kemungkinan bisa memainkan sebuah lagu, dengan variasi nada yang menjadi bahan pertimbangan ketika komponis membuat komposisi, hal tersebut disesuaikan dengan sentuhan pengembangan yang telah kita nalarkan pada alat musik polopalo tersebut.

\section{Unsur Musikal}

a. Melodi

Menurut Karl-Edmund Prier, melodi adalah urutan nada yang utuh dan memberi makna. Bentuk dan jenis melodi tergantung dari sistem tangga nada yang dipakai, fungsi dan konteks budaya yang berkaitan (Karl-Edmund Prier SJ, Ilmu Bentuk Musik, Pusat Musik Liturgi, Yogyakarta, 2009, hal 113).

b. Harmoni

Harmoni dalam bahasa Indonesia memiliki arti keselarasan, yang dalam musik dapat berarti keselarasan bunyi dari beberapa nada yang dibunyikan secara bersamaan. Sistem harmoni mengalami banyak perkembangan sejak jaman barok hingga saat ini modern.

c. Timbre

Timbre atau warna suara merupakan unsur yang penting dalam menciptakan karya musik. Hal ini berkaitan dengan karakter bunyi dan efek yang dihasilkan dari bunyi tersebut. Banyak komposer modern yang telah melakukan eksplorasi bunyi berbagai benda untuk dijadikan instrumen musik baru.

d. Ritme

Ritme atau pola ketukan merupakan susunan dari bunyi dan diam dengan tempo atau kecepatan yang teratur dan durasi atau panjang pendek yang bervariasi. 


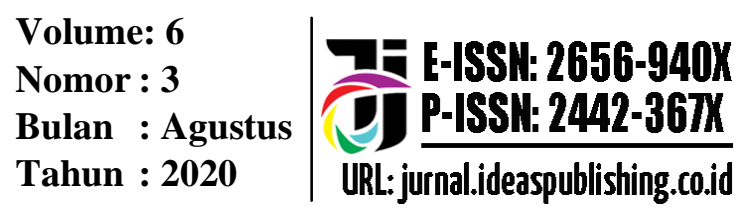

Ritme dapat membantu melodi dalam menciptakan suasana yang dikehendaki composer.

e. Bentuk Musik

Bentuk musik merupakan struktur penyusunan elemen musikal dalam sebuah komposisi musik. Karl-Edmund Prier mengatakan bahwa bentuk musik dapat dilihat secara praktis sebagai sebuah wadah yang di isi dan diolah oleh komponis sehingga menjadi sebuah karya musik yang hidup (Karl-Edmund Prier SJ, Op. Cit. hal 2).

Istilah bentuk musikal digunakan untuk mengenali pola-pola yang lebih kecil yang digunakan di dalam musik vokal dan instrumental. Istilah tersebut diperoleh dari struktur yang ditemukan pada musik berdurasi pendek atau sedang seperti musik-musik rakyat dan himne.

Pembagian struktur utama pada bagian tersebut disebut "parts" (bagianbagian). Oleh karena itu, istilah two-part atau three-partsong form tidak mengacu pada jumlah suara atau instrument yang digunakan, melainkan mengacu pada bagian-bagian utama sebuah karya (Leon Stein, Structure \& Style Expanded Edition, Summy-Bitchard Music, Florida ,1979, p. 57)

Secara umum bentuk musikal tersusun dari bagian pokok dan bagian pembantu. Secara garis besar pola pada bagian pokok mengacu bagian yang ditulis dengan A, B, C, atau bagian I, Bagian II, Bagian III, atau dengan tema utama dan tema pembantu (subordinate theme). Bagian pembantu (auxiliary members) terdiri dari introduksi, transisi, retransisi dan coda.

f. Instrumentasi

Komposisi ini tersusun dari instrumen drum, bass, gitar, keyboard, dan polopalo.

1. Drum kit

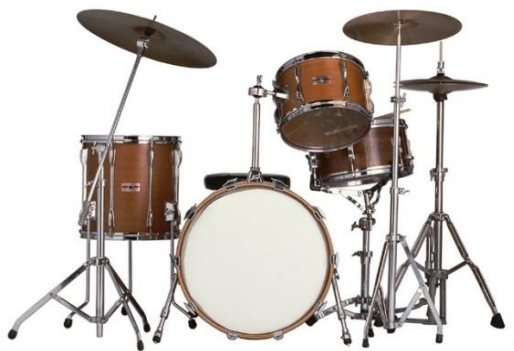

Sumber gambar http://www.dawsons.co.uk/drums-percussion 
Drum kit adalah alat perkusi yang dimainkan oleh satu orang dalam sebuah ansembel. Satu set drum kit pada umumnya terdiri dari, bass drum atau kick, snare, beberapa cymbals. dan beberapa tom.

2. Gitar listrik/electric guitar

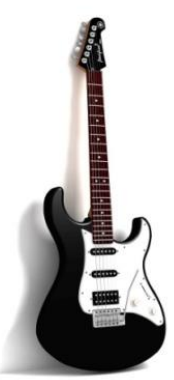

Sumber gambar http://defarisberbagiilmu.blogspot.com/2012/12/gitar

Gitar listrik pada umumnya terbagi dua macam yaitu, hellow dan solid body terdiri dari 21 sampai 24 fret. Perbedaannya dengen gitar akustik terletak pada tranducer (pick up) dan amplifier.

3. Bass listrik /electric bass

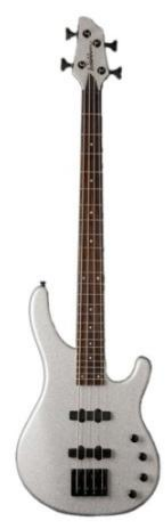

Sumber gambar https://lindoguitars.com/media

Bass tidak jauh berbeda dengen gitar listrik hanya saja gitar bass memiliki ukuran snare lebih besar yang berfungsi memainkan nada-nada rendah (bass) pada sebuah ansembel. 
Volume: 6

Nomor : 3

Bulan : Agustus

Tahun : 2020

4. Keyboard/Synthesizer

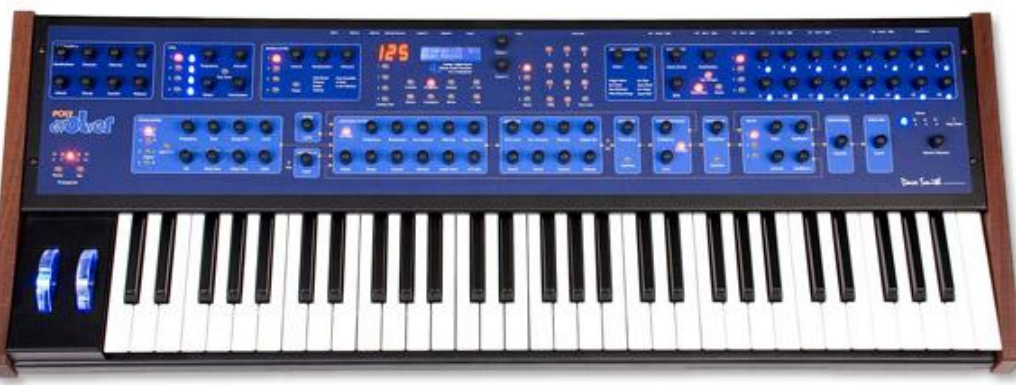

Sumber gambar: http://www.dolphinmusic.co.uk/shop_image

Keyboard / synthesizer dimainkan seperti piano hanya saja perbedaannya keyboard bisa memainkan suara seperti organ, trompet, suling, string, percusi dan lain-lain.

\section{Simpulan}

Saat proses pengkolaborasian polopalo ke dalam karya musik, penulis mengalami beberapa hambatan antara lain adanya keterbatasan nada yang dihasilkan dari bunyi alat musik polopalo, sehingga penulis menempatkan alat musik polopalo tersebut menjadi alat musik perkusi dan kurangnya bunyi alat atau nada yang mirip dengan alat musik polopalo dalam software musik seperti sibelius, fruty loop studio, dan lain sebagainya. Hal tersebut yang menjadikan penulis kurang leluasa dalam proses pembuatan karya musik.

Dari pembelajaran dan penerapan tersebut penulis mengetahui bahwa polopalo dapat dikolaborasikan ke dalam musik rock. Hal tersebut juga tidak menutup kemungkinan alat musik polopalo dapat dikolaborasikan dengan berbagai jenis musik lainnya.

\section{Daftar Rujukan}

Andjani, K. (2014). Apa Itu Musik. Pascawacana: Serpong, Tanggerang Selatan, Pascawacana.

Banoe, P. (2003). Kamus Musik. Kanisius: Yogyakarta.

Bay, S. dan Daulima, F. (2006). Mengenal Alat Musik Tradisional Daerah

Gorontalo. Forum Suara Perempuan: Gorontalo.

Hardjana, S. Musik Antara Kritik dan Apresiasi (Jakarta, Kompas, 2004).

Sadie, Stanley (ed.).(1980). "The New Grove Dictionary of Music Instrument and Musician”. Volume 6. London: Macmillan Publisher Limited.

Persicheti, Vincent. (1961). Twentieth Century Harmony. New York. 
Volume : 6

Nomor : 3

Bulan : Agustus

URL: jurnal.ideaspublishing.co.id Tahun $: 2020$

Prier, Karl-Edmund SJ.( 2009). Ilmu Bentuk Analisis. Pusat Musik Liturgi:

Yogyakarta.

Shadily, Hassan. (1983). Eksiklopedi Indonesia. Ichtiar Baru-Van Hoeve: Jakarta. 
Volume: 6

Nomor : 3

Bulan : Agustus

Tahun : 2020 E-ISSH: 2656-940X
URL: jurnal.ideaspublishing.co.id 